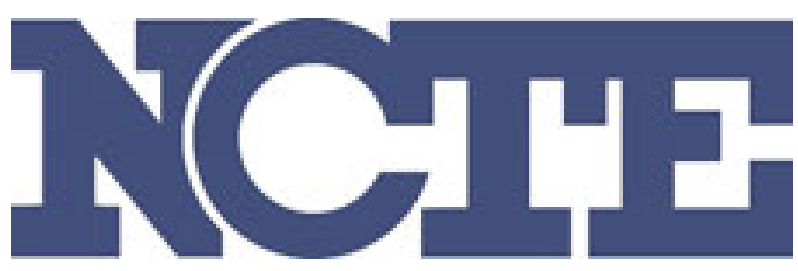

What Students Don't Say: An Approach to the Student Text

Author(s): Margaret L. Shaw

Source: College Composition and Communication, Vol. 42, No. 1 (Feb., 1991), pp. 45-54

Published by: National Council of Teachers of English

Stable URL: http://www.jstor.org/stable/357538

Accessed: 21/02/2014 11:05

Your use of the JSTOR archive indicates your acceptance of the Terms \& Conditions of Use, available at http://www.jstor.org/page/info/about/policies/terms.jsp

JSTOR is a not-for-profit service that helps scholars, researchers, and students discover, use, and build upon a wide range of content in a trusted digital archive. We use information technology and tools to increase productivity and facilitate new forms of scholarship. For more information about JSTOR, please contact support@jstor.org.

National Council of Teachers of English is collaborating with JSTOR to digitize, preserve and extend access to College Composition and Communication. 


\section{What Students Don't Say: An Approach to the Student Text}

\section{Margaret L. Shaw}

The more we read and respond to student writing, the more we are likely to become interested not so much in what students say as in what it is they don't say. What they say, after all, is generally what has gotten them by in the past: the well-composed, polished exposition of received truths we all have come to know variously as themewriting or canned prose.

The sheer quantity and repetition of this kind of common-sense, prepackaged discourse has increasingly led many of us to focus on those moments in the texts when something else can be said to happen: those moments when writers fall silent, refuse or fail to develop certain lines of thinking, or try to smooth over contradictions in their papers. By putting pressure on these places in their papers, we try, instead, to drive a wedge into the cracks of an otherwise closed structure, to make a space for thinking to take place, not only about their subject matter, but about the processes of writing and reading.

In the last ten years, a great deal of composition research into the writing process has resulted in efforts to teach students how to generate material in early drafts of their papers, material that will help them resist settling too soon for closure in their writing. ${ }^{1}$ And even the most traditional models for responding to student papers have tried to address the appearance of "gaps" and contradictions in student papers, even if it be by simply telling the student to "DEV" a sentence or by placing question marks next to the most egregious contradictions. But one reason why traditional marginal comments have often failed in the past is that students invariably read them as directives to tighten up their closed fictions even more, usually by reducing complexity rather than increasing it. ${ }^{2}$ What seems called for, then, is a way of discussing and responding to student texts which would take advantage of what we now know about textual production: a method which would help students rethink

Margaret L. Shaw is assistant professor of English at Virginia Polytechnic Institute and State University where she teaches rhetoric, composition theory, and nineteenth-century women writers. She is currently finishing a book on Charlotte Bronte and the construction of nineteenth-century gendered literacies while continuing related work on the history and politics of composition studies. 
textual discontinuities such as "gaps" and "contradictions" in a positive rather than a negative way. It is in relation to both of these interests (the teaching of textual production and changing attitudes toward what is normally perceived as error) that I find recent literary and critical theory most helpful as a source of new ideas for composition pedagogy. ${ }^{3}$

The theoretical basis for the strategies I use originally comes from the work of the French Marxist Louis Althusser and his student, Pierre Macherey, both of whom are significant for literary criticism through their work on textual production. But, as my title suggests, what I will take from them is actually something they share with a number of other modern thinkers from Freud to Jacques Derrida: their methodological interest in gaps, silences, and contradictions - the discontinuities of texts.

The notion of coherence in written and oral texts comes under suspicion in the work of these theorists primarily because the seamless text is the one most often associated with an oversimplification of experience and thought, with generalized truths or reductive ideologies. Thus, in Freud's Interpretation of Dreams, he tells us,

It is hardly rash to assume that the unintelligibility of the dream's content as it exists in the memory has led to its being recast in a form designed to make sense of the situation. That situation, however, is in the process deprived of its original meaning and put to extraneous uses. But, as we shall see later, it is a common thing for the conscious thought activity of a second psychical system to misunderstand the content of a dream in this way, and this misunderstanding must be regarded as one of the factors in determining the final form assumed by dreams. (276-77)

As a consequence of this misleading transformation of material, the analyst must focus on those moments in the reproduction of a dream or personal narrative when the speaker falls silent, becomes unsure or contradictory. These are the moments, according to Freud, when secondary revision has failed to smooth over the troubling material of one's past (The Question of Lay Analysis), or of the dream's content (Interpretation), and is therefore the best place to begin to open up the dream text.

Focusing on the social and political rather than the psychological and repressed, the so-called Althusserians also reject "readings" of texts which seek coherence. For them, the seamless structure is also always a fiction, but specifically an ideological one. Such a fiction covers up the moments when writers confront contradictions in the ideological commonplaces he is reproducing in their writing:

The concealed order of the work is thus less significant than its real determinate disorder (its disarray). The order which it professes is merely an imagined order, projected on to disorder, the fictive resolution of ideological conflicts, a resolution so precarious that it is obvious in the very letter of the text where incoherence and incompleteness burst forth. (Macherey 155) 
For these theorists, every piece of writing which is not strictly and purely propaganda will have moments when this "precarious" fictive totality breaks down, when one commonplace comes into contradiction with another, or when the writers' reproductions of their experiences spill over or exceed the often reductive narratives they have been using to generate their texts.

Macherey recommends that, at exactly this point, "We should question the work as to what it does not and cannot say," since "it is no longer a question of defects but of indispensable informers" (155). In other words, it is at these moments when a reader has access to what Althusserians and Macherey call the "laws of textual production." Such "laws" vary depending on the particular text, but, for them, all textual production depends on some relationship between what is said and what is not. This is so because to engage in the activity of writing a paper, we must inevitably be selective and choose what details of our experience or subject matter we will attend to. We must bring certain details into the foreground and put others in the background simply because we always approach our material from a point of view and a point of view is always partial. Therefore, a certain number and type of details will be suppressed or silenced as we write, forming what Macherey calls the "non-said" of the text. In the act of writing, we suppress the knowledge of our own suppressions-out of necessity. In other words, we cannot be fully aware of our "laws" of textual production while we are writing or we would not be able to produce anything at all.

But the proposition that writers follow necessary "laws" does not mean that they are following the form of a compositional model or realizing an overriding intent which exists independently of and prior to the text; rather the laws arise from the act of trying to produce a text within a network of existing pressures, many of which function at cross purposes to each other. As Macherey says,

The necessity of the work, if it is an objective determination, is not one of its natural properties, the index of the presence of a model or an intention. The necessity of the work is not an initial datum, but a product, at the point where several lines of necessity converge. The important thing is not a confused perception of the unity of the work, but a recognition of its transformations (its contradictions, as long as contradiction is not reduced to merely a new type of unity). (42)

To capture the work's "necessity," then, and begin the process of revision, writers in a composition class need to examine their essays after they are written, when they and other readers can help expose the strategies of inclusion and exclusion and their implications.

To produce these strategies, we need to rely essentially on one move: turning the text against itself and letting it provide a model for interrogating itself. In other words, what I am suggesting is not simply the codification and application of a set of reading procedures culled from Freud or Althusser-or any other theorist for that matter. Clearly, student papers will vary in the de- 
gree to which contradictions and gaps in the material have been smoothed over and resolved. The more "seamless" the paper, the more difficult it is to apply pressure from within which will open up the text. Therefore, the questions we come up with when we respond to student papers will always be determined by what the paper suggests, not by a theory which is "applied" in any reductive way.

Let me illustrate with some examples taken from freshman composition papers written in a course at the University of Pittsburgh. The course was called General Writing, the University's designation for mainstream, and therefore not Basic or Honors, composition classes within that institution. ${ }^{4}$ They were part of a large program which asked students to read and write on a central set of issues throughout the term, issues which would directly or indirectly lead students into an investigation of what it means to read and write well. In my class, students were asked to write in response to a sequence of twenty-two assignments exploring the topic of conformity and nonconformity, terms I used eventually as metaphors for conventional and unconventional practice in the acts of reading and writing. (Not all of the assignments called for complete papers.) Students read a variety of texts for the course, including Walker Percy's essay on "The Loss of the Creature," a book on grammar by Richard Mitchell, a story by John Updike, a transcript from a Phil Donahue Show, and, of course, a number of student essays produced by members of the class. ${ }^{5}$ The texts were read not only as explorations of a topic (conformity and nonconformity) but also as kinds of advice about the activities of reading or writing.

The first papers I would like to discuss were written in response to an assignment on Emerson's essay, "Self-Reliance." The students were asked to determine some "significant details" of the essay and then discuss how such an essay might be read as advice for someone learning to write. At this point in the series of assignments I was using, I wanted to teach my students to read the essay in complex enough terms that they would then be able to see some of the complexities of and problems with the advice when applied to writing. At the same time, I wanted them to see that how they initially chose to "read" the passage had something to do with a selective and partial point of view.

The first student began her paper by focusing on only one point in the Emerson essay: "All too often," she says, "I have held back from expressing an opinion or presenting an idea, because it was mine and I felt it was worthless, only to hear a similar idea from someone else." What followed was a completely predictable narrative, the parameters of which were predetermined by the student's initial construction of what were the "significant details" in Emerson's essay. Suddenly, in the middle of the narrative, the student wrote, "Conversely, there have been occasions when I have expressed an idea openly, only to feel frustration because it was dismissed without any consideration." But at the very moment the writer began to introduce complexity into her 
paper, she fell silent in the face of what must have appeared to be a dangerous move-disagreeing with Emerson-and returned to her pat narrative about speaking one's mind, never once aware of the irony of what she had done. The writer ended her paper with the following paragraph:

At times sounding like a preacher and other times like someone giving fatherly advice, Emerson stressed the importance of just being yourself, not imitating others because, "Your own gift you can present every moment . . . but of the adopted talent of another you have only an extemporaneous half possession." In making reference to great writers, inventors, and scientists, Emerson alludes to the significance of what society would be missing had all or any of those great people "[dismissed] without notice his thought because it [was] his." Therefore, each one of us may be harboring an act of genius inside waiting to be set free for, "That which each can do best . . . [n]o man yet knows what it is, nor can, till that person has exhibited it." By not listening to or sharing with others our impressions, each person could be denying society their contribution.

This failure to follow Emerson's advice (to rely on one's own voice) while praising that advice produced an interesting contradiction in the paper, one which an instructor might want to push.

One way to begin would be to turn Emerson's text against itself and then do the same with the student's. Thus, the first comment might be an overt directive to read apparent contradictions into Emerson's text-the contradiction implicit in giving the advice to not follow advice-in order to urge the writer to consider the passage more critically. For example, immediately following her first sentence, one might write, "Does it seem odd to you that Emerson would ask us to be self-reliant and to follow his advice at the same time? Is this a contradiction? If so, can you get him off the hook?" A second comment might then ask the writer to turn her own text against itself and explore how well it enacts its own claims. After the last two sentences of the paragraph, the teacher might ask, "Do you think you may have done this as well when you began to disagree with Emerson earlier in your paper? Can you turn your answer into some advice for yourself about revising this paper?" This procedure asks the student to distance herself from her paper and to see how her own argument has been too simple to cover her experience, how Emerson's advice has been read too simply, or both. Whatever she concludes, the final question asks her to consider how she would apply her answer to a revision of her paper, one which may lead her to some of the complexities in both Emerson's and her own thought which were lost in pursuit of the safe and seamless narrative.

A similar method can be used to discuss papers in class. The following paper is composed of a series of fairly coherent paragraphs, none of which is significantly connected to the others:

In Emerson's essay, “Self-Reliance," Emerson, using voice effectively, establishes a relationship with the reader which makes the reader willing to 
believe what he says. Formal and eloquent, Emerson's voice makes the reader aware of the profundity of his words. Much of Emerson's phrases are similar to, if not directly from the Bible. Emerson also addresses the reader as "YOU". This adds to the sermon-like effect of the essay.

Admiring the originality of great works and great men, Emerson feels that much greatness has an important lesson and a definite effect on us. Affecting us in different ways this greatness can hinder or promote our own greatness. When considering a great work, or act, or man, we tend to see the ways of others as our way to greatness. On the other hand, when considering great achievements, we can also be inspired to follow our own hearts. The latter example exemplifies the lesson to be learned from great achievements. The lesson is to rely on our own feelings. Otherwise, we may never realize a completely unique quality within ourselves.

Though Emerson's advice is sound and well-stated, few people are likely to seriously consider such advice. People concern themselves more with acceptance, popularity, and being in the majority than with fidelity to their own self. Thus it becomes a matter of values. The values of the majority do not lie in originality, but in acceptance. This is why there are so few great people.

Emerson's position is sound advice for the student writer. This is so because a writer at this stage has not developed a style or purpose for his writing. Considering Emerson's advice, one can easily determine who to trust while growing into an effective writer.

The first paragraph, unlike the summary of Emerson's essay which follows it, was actually in response to a question raised in class about Emerson's use of language and how it helps establish his authority. My first question to the class, then, was, "To what is this paragraph an answer?" Once the students had established the paragraph as an answer, not to the assignment, but to the question from the previous class, they were able to determine "questions" for each of the other paragraphs, only some of which had to do with the actual paper topic. It soon became clear that the writer's central strategy for generating the text was simply to respond to a series of discussion questions without any real attempt to think through connections, a common enough writing strategy. At the same time, because the writer was fairly articulate, he could rely on bald assertions and superficial logical constructions, such as in paragraphs two and three, to cover over what he doesn't say. The problem, then, was to see if the gaps between paragraphs and between individual assertions could be made productive.

Once the class realizes that paragraph one is an answer to the question "How does Emerson establish his authority through his use of language?" a teacher can ask, "How, then, does the writer of this paper try to establish his authority?" By turning the writer's text against itself, the instructor can point students to the efficient, rather cool summary of paragraph two and to the generalizations of three and four. They could then describe the kind of person speaking in paragraphs three and four, how old he seems to be, etc., until it becomes clear that the writer's authority rests almost entirely on our willing- 
ness to remain deaf to what he has failed to say, to accept his relatively uncomplicated and assured selection of details as the picture of the "way things are."

Having established how the writer distracts his readers from the gaps between his paragraphs, an instructor can then ask the students what the writer doesn't say about Emerson's essay or about student writers that might lead us to some real connections between these paragraphs. At this point, students usually begin to talk about why, if the writer believes few people would seriously consider Emerson's advice, does he go on to say it is sound advice for the student writer. Turning the text against itself, the teacher can ask the class whether or not the student follows Emerson's advice himself or if the "I" of the text is also concerned about acceptance and conformity more than selfreliance. But another direction could be followed just as well. One might go on to ask whether or not writing belongs in the area where one seeks popularity and acceptance. And if so, how does that affect one's writing process? Or the class might consider exactly what it means to rely on one's "own feelings."

The concept of the productive gap or contradiction can be repeated in the sequence of assignments we give our students, reinforcing the notion that everything we do in class is essentially "responding to" a text. The Eddington assignment below is ninth in the sequence of twenty-two on conformity and nonconformity. ${ }^{6}$ In it, students are asked to read a passage from Sir Arthur Eddington's Stars and Atoms which sets up an opposition between a cautious Daedalus and an incautious Icarus and then to discuss the mythological figures as types of writers; in this way, the assignment invites students to consider the possible productive value of pushing their writing until "hidden weaknesses" are actually exposed rather than covered over, as a "Daedalus Writer" might well do:

\section{SIR ARTHUR EDDINGTON AND THE TWO SCIENTISTS}

In Stars and Atoms, Sir Arthur Eddington describes two kinds of scientists by way of comparison between the classical figures Daedalus and Icarus:

In ancient days two aviators procured to themselves wings. Daedalus flew safely through the middle air and was duly honored on his landing. Icarus soared upwards to the sun till the wax melted which bound his wings and his flight ended in fiasco. In weighing their achievements, there is something to be said for Icarus. The classical authorities tell us that he was only "doing a stunt," but I prefer to think of him as the man who brought to light a serious constructional defect in the flying-machines of his day. So, too, in science. Cautious Daedalus will apply his theories where he feels confident they will safely go; but by his excess of caution their hidden weaknesses remain undiscovered. Icarus will strain his theories to the breaking-point till the weak joints gape. 
Although Eddington is talking about scientists, we could read this passage as relevant to conformists and nonconformists in areas other than the scientific as well. What two kinds of writers, for instance, could be represented through the figures of Daedalus and Icarus? Which type of writer do you imagine Eddington would prefer?

Write a paper in which you explain Eddington's position in this passage and how it might be said to define a certain kind of conformist and nonconformist. In this paper, you should also respond to Eddington's position on the basis of your own specific experience as a writer. How can what he says be applied to you as a writer-or to writers in general-as well as to scientists? Do you share his preferences or not?

The notion of pushing ideas to the breaking point is examined from another point of view through Walker Percy's essay "The Loss of the Creature" and then, in the twenty-first assignment below, from yet another perspective in a passage from William Gordon's Synectics. In this rather complex passage, Gordon discusses how creating discontinuities in our conventional laws of vision can help us break through to new ways of seeing things:

\section{WILLIAM GORDON AND SOME "LAWS OF VISION"}

William Gordon, in his book Synectics, approaches the problem Percy describes from a slightly different angle. Here is one paragraph from his book:

To break through toward a creative act, it is necessary to twist out of phase whatever conventional laws appear to hold. This does not mean that it is necessary to defy all the basic hypotheses of our phenomenology, but that it is necessary to defy them apparently. Then, through the cracks which appear when the laws are twisted out of phase (all this attained through conscious self-deceit), things can be seen in a new way. So long as the rules are accepted as immutable "laws of vision" the world will appear to be the same and no novelties can be discovered or fabricated. Many highly trained people naturally tend to think in terms of the dogma of their own technology and it frightens them to twist their conventions out of phase. Their conventions sometimes constitute a background of knowledge upon which they rely for their emotional stability. Such experts do not want cracks to appear. They identify their psychic order with the cosmic order and any cracks are signs of their orderly cosmos breaking up.

For this paper, describe a time when you had to revise a conventional view of someone or something, a view Percy would call a pre-formulated "symbolic complex."

In your description, make clear what that conventional view was as well as what caused the "cracks" in your conventional "laws of vision." In other words, what is it that made you aware of your view as a conventional one? And how did you respond? Were you, like the experts in Gordon's passage, horrified at what happened? Or, like Percy's complex tourist, were you excited by the new view? Or was your response different from either of these?

And finally, when you are through with your description, go on to discuss what it means in general for someone to revise a view of some- 
thing. This discussion should, of course, be based on what you have discovered in your description, but feel free to include any other information you may have on this subject.

The assignment asks the students to write about a time when their own "laws of vision" were twisted out of phase sufficiently for them to see something in a new light and to apply what they have learned from that to the notion of revision. By repeating the method of responding to their written work in a different form in their assignments, the teacher can introduce over time a concept which is difficult for students to grasp simply by reading marginal comments.

The purpose of this repeated focus on discontinuity is not, however, to end up with just another ideological fiction-albeit a more sophisticated one. Rather the point of such a way of responding to texts and constructing assignments is to open up the undecidability of any piece of writing, to get to certain root issues about the composing process that can't, finally, be resolved. Why move to these root issues? First, to show students that any piece of writing is always already implicated in a reading of the material at hand, that it is always partial, but never simply relative. And second, to show them that this recognition of undecidability can be immensely productive.

In fact, to know that our views are conditional and dependent on simplification and suppression is already to have accepted a new point of view about writing, one which can provide a strong motivation for revision. To revise a point of view or a piece of writing, we need to see how we have seen, how we made a point of view in the first place. And it is only in the gaps and breaches of discourse that alternative discourses arise. By teaching students to look for a relationship between what they say and what they don't say in their writing, we can teach them that it is possible to establish new configurations, to change their minds, if they choose. And pushing their writing to the breaking point, looking for rather than covering over gaps and contradictions, may teach students that writing is an opportunity to go beyond the reproduction of the commonplace to explore new ways of seeing.

\section{Notes}

1. See especially, Nancy Sommers, "Revision Strategies of Student Writers and Experienced Adult Writers," and "Responding to Student Writing"; Lester Faigley and Stephen Witte, "Analyzing Revision"; Richard Beach, "The Effects of Between-Draft Teacher Evaluation versus Student Self-Evaluation on High School Students' Revising of Rough Drafts”; Donald Murray, "Teaching the Other Self: The Writer's First Reader"; and Linda Flower et al., "Detection, Diagnosis, and the Strategies of Revision."

2. For further discussion of how typical responses to student writing fail, see W. U. McDonald, "The Revising Process and the Marking of Student Papers," and C. H. Knoblauch and Lil Brannon, Rhetorical Traditions and the Teaching of Writing.

3. For other examples specifically related to composition pedagogy, see Robert Brooke's comments on play in "Control in Writing: Flower, Derrida, and Images of the Writer"; C. Douglas Atkins and Michael L. Johnson, eds., Writing and Reading Differently: Deconstruction and the Teaching of Composition and Literature; and Cary Nelson, ed., Theory in the Classroom. 
4. For a more complete description of the types of writing done by students falling under Pittsburgh's rubrics of Basic and General writers, see David Bartholomae, "Inventing the University."

5. The book by Mitchell was Less Than Words Can Say and the Updike Story was "A \& P." For further discussion of this sequence and how a modified version can be used to teach revision in a basic writing class, see Margaret L. Shaw, "Teaching Revision as Re-Seeing: Sequenced Assignments for Basic Writing."

6. My thanks to Lynn Buncher, University of Pittsburgh, for calling my attention to the Eddington passage.

\section{Works Cited}

Althusser, Louis, and Etienne Balibar. Reading Capital. Trans. Ben Brewster. London: NLB, 1970.

Atkins, C. Douglas, and Michael L. Johnson, eds. Writing and Reading Differently: Deconstruction and The Teaching of Composition and Literature. Lawrence: UP of Kansas, 1985.

Bartholomae, David. "Inventing the University." Perspectives on Literacy. Ed. Eugene R. Kintgen, Barry M. Kroll, and Mike Rose. Carbondale: Southern Illinois UP, 1988. 273-85.

Beach, Richard. "The Effects of Between-Draft Teacher Evaluation versus Student SelfEvaluation on High School Students' Revising of Rough Drafts." Research in the Teaching of English 13 (May 1979): 111-19.

$\rightarrow$ Brooke, Robert. "Control in Writing: Flower, Derrida, and Images of the Writer." College English 51 (April 1989): 405-17.

Eddington, Sir Arthur. Stars and Atoms. New Haven: Yale UP, 1927.

$\rightarrow$ Faigley, Lester, and Stephen Witte. "Analyzing Revision." College Composition and Communication 32 (Dec. 1981): 400-14.

$\rightarrow$ Flower, Linda, et al. "Detection, Diagnosis, and the Strategies of Revision." College Composition and Communication 37 (Feb. 1986): 16-55.

Freud, Sigmund. The Interpretation of Dreams. Trans. and ed. James Strachey. New York: Avon, 1965.

The Question of Lay Analysis. Trans. and ed. James Strachey. New York: Norton, 1978.

Gordon, William. Synectics: The Development of Creative Capacity. New York: Harper, 1961.

Knoblauch, C. H., and Lil Brannon. Rhetorical Traditions and the Teaching of Writing. Upper Montclair: Boynton, 1984.

$\rightarrow$ McDonald, W. U. "The Revising Process and the Marking of Student Papers." College Composition and Communication 24 (May 1978): 167-70.

Macherey, Pierre. A Theory of Literary Production. Trans. Geoffrey Wall. London: Routledge, 1978.

Mitchell, Richard. Less Than Words Can Say. Boston: Little, 1979.

$\rightarrow$ Murray, Donald. "Teaching the Other Self: The Writer's First Reader." College Composition and Communication 33 (May 1982): 140-47.

Nelson, Cary, ed. Theory in the Classroom. Chicago: U of Illinois P, 1986.

Percy, Walker. "The Loss of the Creature." Message in the Bottle. New York: Farrar, 1975. $46-63$.

Shaw, Margaret L. "Teaching Revision as Re-Seeing: Sequenced Assignments for Basic Writing." Iowa English Bulletin 32.1-2 (1983): 1-4.

$\rightarrow$ Sommers, Nancy. "Responding to Student Writing." College Composition and Communication 33 (May 1982): 148-56.

$\rightarrow-$ "Revision Strategies of Student Writers and Experienced Adult Writers." College Composition and Communication 31 (Dec. 1980): 377-88.

Updike, John. “A \& P." Pigeon Feathers and Other Stories. New York: Knopf, 1962. 187-96. 